\title{
Sustainable Construction in Oman: the Potential Role of THE INDUSTRIALIZED BUILDING SYSTEMS
}

\author{
M. S. Saleh, and C. Alalouch" \\ Civil and Architectural Engineering Department, College of Engineering, Sultan Qaboos University, P.O. Box 33 \\ Al-Khoudh, Muscat 123, Oman
}

\begin{abstract}
The Omani construction industry has been recently witnessing a boosted expansion associated with the notable growth in population and economy. In comparison with its neighboring countries, the construction industry in Oman is criticized for the lack of sustainability practices. Recently, the government and professional bodies have taken proactive actions to promote sustainable construction practices. The Industrialized Building Systems (IBS) could play an important role in the Omani construction industry in the future due to its environmental, economic, and social benefits. However, the lack of evidence on the contribution of IBS to the Omani construction industry suggests that this approach is not yet at the top of the stakeholder agenda. This paper focuses on the potential contribution of IBS to sustainable construction practices in Oman. Through a literature review, a comprehensive list of sustainability factors affecting IBS applications in the Omani construction industry was developed. A stakeholder survey of Omani construction industry including clients, engineers, and contractors was conducted to understand their perception on the importance of these factors. Statistical analysis revealed that the environment-related and the implementation-related factors are more important than the social-related factors. The economic-related factors were not found to be significantly more important than any other group of factors. Moreover, construction-time was found to be the most important and the most influential factor among the 62 factors considered in this study. The paper concludes with recommendations to promote and improve applications of industrialized building system in the Omani construction industry.
\end{abstract}

Keywords: Construction industry; Industrialized building system (IBS); Oman; Sustainable construction; Sustainability.

\section{الإنشاء المستّام في عمان: دور أنظمة الإنشاء المصنعة}

$$
\text { م. ص. صـالـح و ش. العــــوش* }
$$

الملخص: يشهد قطاع الإنشاء والتعمير في عمان نهضة كبيرة بسبب ازدياد أعداد السكان وتحسن الوضع الاقتصادي في

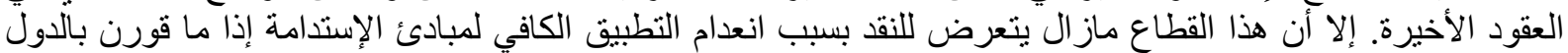

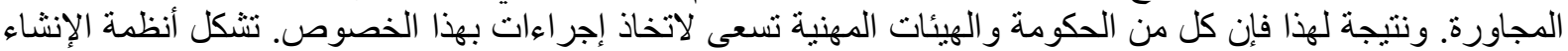

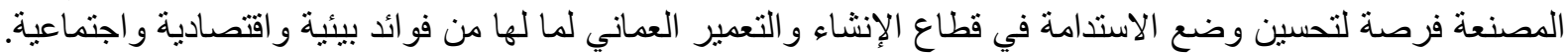

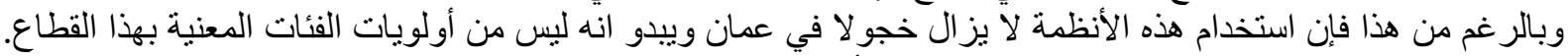

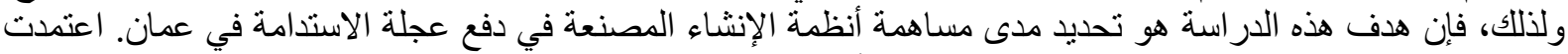

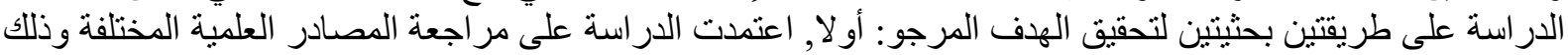

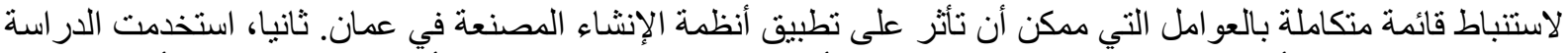

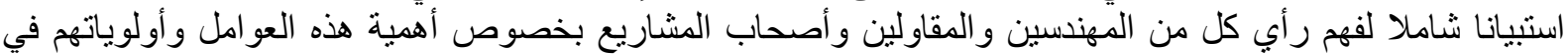

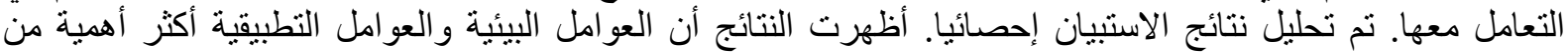

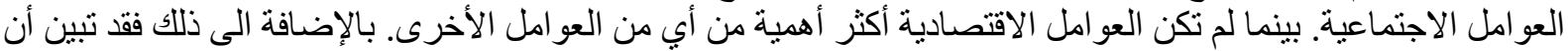

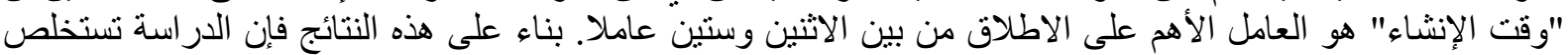

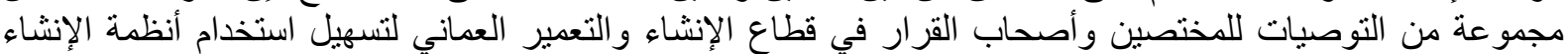

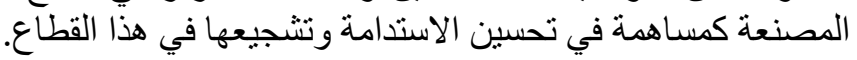

الكلمات المفتاحية: قطاع الإنشاء والتعمير؛ أنظمة الإنشاء مسبقة الصنع؛ أنظمة الإنشاء المصنعة؛ عمان؛ الإنشاء المستدام؛ الاستدامة.

*Corresponding author's e-mail: c.alalouch@squ.edu.om 


\section{INTRODUCTION}

In spite of the cutbacks of public investments and the broad slowdown in the economy due to reduction in oil prices, the construction sector in Oman is still growing at a steady rate. In real terms, the construction projects registered in Oman were reported to grow by $9.4 \%$ annually during 2012-2016 (Timetric, 2017). The construction sector is the largest segment of the non-oil economy in Oman and as such, it remains a pillar in the government endeavor for diversification of the country's economy toward its long-term Vision 2040 (Oxford Business Group, 2018).

Achieving and maintaining sustainable development has become increasingly more prevalent for many countries over the last decades. In line with its neighboring countries, Oman has made plans for economic diversification to reduce its dependency on the fast depleting oil reserves, through building competencies across other sectors of the economy (The World Bank). Subsequently, the government had allocated huge investments on infrastructure, housing projects, and industrialization which had led to a tremendous boom across the construction industries (Oxford Business Group, 2013). This huge development is accompanied by the raising demand to maximize the efficient use of natural resources. The current global economic slowdown had put pressure on the Omani government to take steps to address issues related to quality, sustainability, and standardization in the construction sector to meet its needs and to bring its construction industry in par with international standards. The government of Oman has taken several actions to promote the development of sustainable construction practices. In spite of these efforts, many recent studies showed that the construction industry in Oman still lacks evidence of sustainability practices. Saleh and Alalouch (2015) have addressed several major challenges to the application of sustainable construction in Oman and grouped them into four major clusters: economic, capacity/professional, societal, and technological challenges. Similarly, Powmya and Abidin (2014) found that most of the stakeholders in Oman believe that applying sustainable practices in Oman would result in a dramatic raise in construction cost without any quantifying benefits, a view that is considered a challenge by itself. Moreover, Alalouch et al. (2016), in their comparative study of two energy-efficient houses in Oman and Qatar, concluded that applying sustainability practices in Oman still at early stages which require vast shifts in the construction industry. In a more recent study, the energy-saving potential in a residential building in Oman was explored. The result showed the potential for great saving in energy when energy passive measures are put in place (Alalouch et al., 2019). In fact, several recent research efforts have been focusing on the urban expansion in Oman (e.g. Alalouch et al. 2019; Alkamali et al.
2017).

On the other hand, the industrialized building systems can respond to many challenges in the construction sector in Oman. Zhang sees the IBS to be the future of the construction industry worldwide due to its ability for capitalizing on the strength of the industrial production (Zhang, Skitmore, and Peng, 2014). Industrialization from the construction point of view is considered part of the modernization process through developing methods of production and technology systems, where production operations are centralized, mechanized, and mass productionoriented (Lessing, 2006). Warszawski (1999) explained that an industrialization process is an investment in technology facilities and equipment, aiming at maximizing production output, minimizing demand on labor, and improving quality (Nawi et al., 2014).

Therefore, the objective of this study is to identify the sustainability criteria for IBS and assess their importance as perceived by the construction industry stakeholders in Oman. Recommendations that are proposed in this study could be used by different stakeholders to help to promote and improving the application of IBS in the Omani construction industry.

\section{SUSTAINABILITY ASPECTS OF IBS}

Though prefabrication and standardization terminologies are still in use, Industrialized Building System (IBS) has become the most common term used to represent those terminologies due to the research context of the Malaysian construction industry (Nawi, et al., 2014). Industrialized building construction is defined as a generic process of rationalization and standardization of work processes in the construction industry to reach cost efficiency, higher productivity and quality (CIB, 2010). A more elaborate definition for industrialized building construction is a change of thinking and practices to improve the production of construction and to produce high quality, custom-built, and environmentfriendly buildings through an integrated process, optimizing standardization, organization, cost, value, mechanization and automation (CIB, 2010).

The Industrialized Building Systems (IBS) is considered by several researchers to be the cornerstone rising for improving the construction industry, e.g. (Cook, 2005; Hampson and Brandon, 2004). This is due to the manufacturing of construction components in a controlled environment, either at-site or off-site, then installed or assembled into construction works. Although many studies have focused on the implementation of the IBS, there is a debate on its potential effect on the construction industry. For example, some studies considered that IBS is more expensive than conventional construction systems (Birkbeck and Scoones, 2005); while other studies found that project cost had been reduced remarkably due to IBS use over time (Goodier and 
Table 1. IBS features that promote sustainability (Richard, 2006).

\begin{tabular}{|c|c|}
\hline Perspective & Criteria \\
\hline \multirow[b]{2}{*}{ Economy } & $\begin{array}{l}\text { 1. Reproduction, which ensures higher } \\
\text { productivity and quality }\end{array}$ \\
\hline & $\begin{array}{l}\text { 2. Simplified processes, which reduces } \\
\text { the total energy involved }\end{array}$ \\
\hline \multirow{4}{*}{$\begin{array}{l}\text { Factory } \\
\text { production }\end{array}$} & $\begin{array}{l}\text { 3. Working conditions to avoid losing } \\
\text { time through severe weather }\end{array}$ \\
\hline & $\begin{array}{l}\text { 4. Waste reduction due to modular } \\
\text { coordination, bulk purchasing and factory } \\
\text { applied finishes }\end{array}$ \\
\hline & $\begin{array}{l}\text { 5. Factory conditions, which avoid later } \\
\text { repairs }\end{array}$ \\
\hline & $\begin{array}{l}\text { 6. Precision in production keeping the } \\
\text { construction site clean and free of debris }\end{array}$ \\
\hline \multirow[b]{2}{*}{ Adaptability } & $\begin{array}{l}\text { 7. Flexible components, which allow for } \\
\text { planning changes }\end{array}$ \\
\hline & $\begin{array}{l}\text { 7. Demountable components, which } \\
\text { allow for a major reconfiguration and } \\
\text { relocation without demolition waste }\end{array}$ \\
\hline
\end{tabular}

2007; Gibb and Isack, 2003). On the other hand, IBS has been linked to green construction (Jaillon and Poon, 2009; Zhang and Skitmore, 2012).

The sustainability aspects of implementing IBS practices can encourage the coordination between the built environment and construction processes, thus creating urban settlements that affirm healthy environments, social interaction, and encourage economic development. Richard identified eight key sustainability benefits of applying prefabrication in construction (Richard, 2006); as listed in Table 1. The following highlights the environmental, economic and social sustainability aspects of IBS in construction.

\subsection{Environmental Aspects}

The environmental benefits derived from implementing IBS practices will vary according to the specific system implemented. With no doubt, typical traditional construction could have a better environmental performance over some prefabrication systems, but still the potential exists for IBS practices to have better environmental performance if they were well implemented and managed. As reported by Waskett (2001), one specific program being developed with the European-Commission backing has the potential anticipated benefits associated with IBS of a $50 \%$ reduction in the amount of water used for the construction of a typical house, and a 50\% reduction in the use of quarried materials used in the construction. Another environmental benefit of using IBS elements is that conventional formworks could be eliminated or greatly reduced, which will reduce the issue of construction waste and its subsequent environmental problems. Prefabrication can also promote a safer working environment for construction workers. The need of a large number of workers and raw materials are also noticeably reduced at the sites. In addition, as products are manufactured in a controlled environment and standard in sizes, wastage will be minimized at both factory and construction sites (Bari, et al., 2012).

Equally important, IBS has the potential to accommodate modern and smart building energy systems (mechanical, electrical, fire safety, etc.) that are known for their high environmental performance as IBS has been seen as the future of the construction industry (Zhang, Skitmore, and Peng, 2014) and linked to green construction (Jaillon and Poon, 2009).

\subsection{Economic Aspects}

There are many economic benefits for implementing IBS practices in construction; among them are cost savings, quality, and speed of construction. Operation and maintenance costs are reduced due to the highquality characteristics of prefabricated components. Yunus and Yang (2011) mentioned that the cost of labor and materials will be also reduced significantly by adopting IBS. On the other hand, Kamaruddin et al. (2013) revealed that a considerable number of contractors are unwilling to take part in projects that include IBS. This is due to the higher costs associated with the procurement of materials and hiring welltrained labour despite the overall cost saving it offers. Jaillon and Poon (2009) concluded that adopting IBS practices in a project could lead to an overall reduction of $16 \%$ of labour costs, as well as $15 \%$ of total construction time. In addition, Goodier and Gibb (2007) and Ding (2008) emphasized that due to its standardization process; IBS will result in a significant time saving, improve quality control, and reduce material. To achieve these benefits all of the construction team must realize and understand the sustainability potential of IBS. This review demonstrates the sustainability potential of IBS as one of the modern construction systems that could achieve better economic viability if it is properly utilized and implemented.

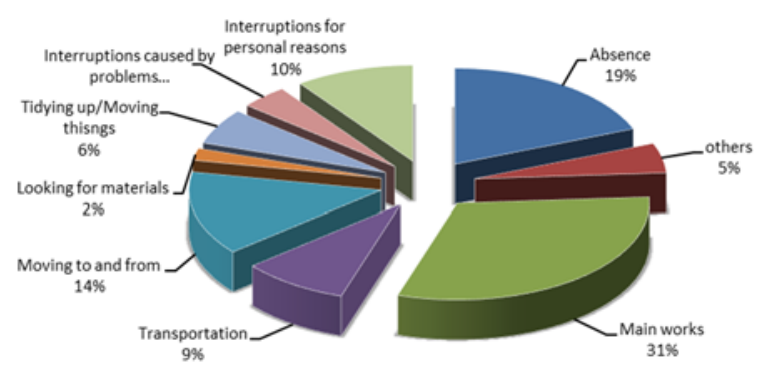

Figure 1. Potential reduction in cost when industrialized construction is used (CIB, 2010). 


\subsection{Social Aspects}

Adopting prefabrication in construction will have a remarkable effect on the labour market. Investing in automation will help in reducing the dependence on unskilled workers and foreign labours (El-Abid and Ghazalia, 2015). Prefabrication can also promote healthier working environments as a result of cleaner and safer construction sites. In addition, it improves the health of the building's occupants by controlling moisture and volatile organic compounds levels in a factory setting. Controlling the quality of building components will lead to minimizing risks of chronic health issues of occupants (Ghaffarianhoseini, et al. 2018). In urban areas, traffic disruption to congested roadways due to construction activities is very crucial. Traditional construction practices usually result in pollution, noise, dust, and require more trips to the construction site. On the contrary, IBS can reduce onsite construction activities and time, which inevitably reduce the disturbance associated with construction. In addition, prefabricated units are normally transported in large sizes leading to a limited number of trips to the site, and thus creating less disruption to the congested city traffic and the local community.

\section{DEVELOPMENT OF A COMPREH- ENSIVE LIST OF SUSTAINABILITY FACTORS FOR IBS APPLICATION}

A literature review was conducted aiming at developing a comprehensive list of typical sustainability factors affecting the quality of IBS implementation. Although the implementation of IBS practices vary from a country to another, some applications reflect the adoption of IBS in developing countries like Oman. Among these applications are 'Standardization' (Gann, 1996; Lessing, Stehn, and Ekholm, 2005; Pasquire, Gibb, and Blismas, 2004), 'Prefabrication' (Dawood, 1996; Song, 2005) and 'System Building' (Finnimore, 1989; Luo, Riley, Horman, and Kremer, 2008). Sustainability factors related to these applications were reviewed, summarized and categorized according to the main pillars of sustainability, which are economy, environmental, and social, in addition to implementation-related factors. It is worth mentioning that each factor could have been broken further into "indictors", but this would have resulted in an unmanageable number of variables. Equally important, this study focuses on identifying and evaluating the overarching factors that might facilitate or hinder the implementation of IBS in Oman. Hence, the literature review was limited to the factors only as summarized in Table 2.
Table 2. Sustainability factors for IBS application.

\begin{tabular}{|c|c|c|}
\hline \multicolumn{3}{|c|}{ ECONOMIC-RELATED FACTORS } \\
\hline Criteria & Code & Factors \\
\hline \multirow{6}{*}{ Cost } & Ec-01 & Maintenance and operation costs \\
\hline & Ec-02 & Disposal costs \\
\hline & Ec-03 & Life cycle costs \\
\hline & Ec-04 & Initial construction costs \\
\hline & Ec-05 & Material costs \\
\hline & Ec-06 & Labour cost \\
\hline \multirow[t]{6}{*}{ Time } & Ec-07 & Construction time \\
\hline & Ec-08 & Lead-times \\
\hline & Ec-09 & Speed of return on investment \\
\hline & Ec-10 & Transportation and lifting \\
\hline & Ec-11 & Production \\
\hline & Ec-12 & Design stage adoption \\
\hline \multicolumn{3}{|c|}{ SOCIAL-RELATED FACTORS } \\
\hline Criteria & Code & Factors \\
\hline \multirow[t]{7}{*}{ Social Issues } & Sc-01 & Local economy \\
\hline & Sc-02 & Participation and control \\
\hline & Sc-03 & Community disturbance \\
\hline & Sc-04 & Traffic congestion \\
\hline & Sc-05 & Public awareness \\
\hline & Sc-06 & Public participation \\
\hline & Sc-07 & Principles and values \\
\hline Labour & Sc-08 & Influence on job market \\
\hline \multirow[t]{2}{*}{ Market } & Sc-09 & Knowledge and skills \\
\hline & Sc-10 & Labor availability \\
\hline Safety and & Sc-11 & Workers' health and safety \\
\hline \multirow[t]{2}{*}{ Health } & Sc-12 & Working conditions \\
\hline & Sc-13 & Disaster preparedness \\
\hline Design and & Sc-14 & Site attributes \\
\hline Arch issues & Sc-15 & Aesthetic options \\
\hline \multicolumn{3}{|c|}{ ENVIRONMENT-RELATED FACTORS } \\
\hline Criteria & Code & Factors \\
\hline \multirow{2}{*}{ Waste } & En-01 & Waste generation \\
\hline & En-02 & Waste disposal \\
\hline Energy & En-03 & Embodied energy \\
\hline \multirow{2}{*}{ Consumption } & En-04 & Design and construction \\
\hline & En-05 & Operational energy \\
\hline \multirow[t]{2}{*}{ Recycle } & En-06 & Recyclable / renewable contents \\
\hline & En-07 & Reusable / recyclable elements \\
\hline \multirow[t]{6}{*}{ Pollution } & En-08 & Site disruption \\
\hline & En-09 & Pollution generation \\
\hline & En-10 & Environment administration \\
\hline & En-11 & Ecology preservation \\
\hline & En-12 & Health of occupants (indoor air quality) \\
\hline & En-13 & Inclusive environment \\
\hline Resource & En-14 & Water consumption \\
\hline \multirow[t]{2}{*}{ Consumption } & En-15 & Land use \\
\hline & En-16 & Material consumption \\
\hline IMPLEMEN & ATION-R & LATED FACTORS \\
\hline Criteria & Code & Factors \\
\hline Technical & Tc-01 & Durability \\
\hline Quality & Tc-02 & Defects and damages \\
\hline & Tc-03 & Loading capacity \\
\hline & Tc-04 & Integration of building services \\
\hline & Tc-05 & Integration of supply chains \\
\hline & Tc-06 & Constructability \\
\hline & Tc- 07 & Usage efficiency \\
\hline & Tc- 08 & Adaptability and flexibility \\
\hline & Tc-09 & Technology \\
\hline Enforcement & $\operatorname{Im}-01$ & Standardization \\
\hline & Im-02 & Governance \\
\hline Regulations & $\mathrm{Im}-03$ & Legislation \\
\hline & Im-04 & Policy and strategy match \\
\hline & $\operatorname{Im}-05$ & Building capacity \\
\hline & Im-06 & Design standard and project function \\
\hline & $\operatorname{Im}-07$ & Project control guidelines \\
\hline & Im-08 & $\begin{array}{l}\text { Integrated environmental and } \\
\text { economic program }\end{array}$ \\
\hline & Im-09 & Procurement system \\
\hline
\end{tabular}




\section{DATA COLLECTION AND ANALYSIS}

\subsection{Survey Design and Sample Characteristics}

The survey aimed to investigate the perspective of the Omani construction industry's stakeholders on the relative importance of sustainability factors for IBS applications in Oman. A pilot study was conducted to ensure the effectiveness of the survey; accordingly, it was developed and distributed to the target groups.

The questionnaire survey consisted of three parts. The first part focused on collecting background information about the respondent including years of experience in the construction industry, profession, organization, and the number of IBS projects. In the second part, respondents were asked to rate the importance of each sustainability factor; presented in Table 2; with respect to the IBS applications. A fivestep Likert-scale was used, in which (1) refers to "least significant" and (5) "most significant". To ensure consistency in understanding the factors across participants, the questionnaire included a clarifying definition for each factor. In the third part, respondents were given the opportunity to provide supplementary factors in an open-ended question.

A total of 80 questionnaires were distributed and only 54 responses were received, which gives an overall response rate of $67.5 \%$. Among those 54 respondents, $19 \%$ were from clients/developer sub-group, $43 \%$ from consultants/designers, $19 \%$ from governmental institutes, and $13 \%$ from contractors. Furthermore, $50 \%$ of the respondents were practicing as engineers, $26 \%$ architects, and $15 \%$ project managers. All of the survey participants had professional experience with industrialized building systems. About 52\% had an experience of less than 5 years, while $48 \%$ had more than 5 years of IBS experience. Fig. 2 shows a detailed distribution of respondents among different sub-groups.

\subsection{Data Analysis and Discussion}

In order to identify the most important factors as perceived by the respondents, the data was analyzed statistically. For the purpose of this study, descriptive analysis and tests of differences of the important data of the factors considered are reported.

\subsubsection{The importance of the categories of factors}

The first question in this study was to identify the most important group of factors as perceived by the respondents. Hence, the mean score for the factors in each one of the four categories was calculated across all responses. Fig. 3 shows that the Environmentrelated factors are seen as the most important group of factors followed by the implementation-related factors. The least important group was the socialrelated factors whereas the Economic-related factors came in the third place.

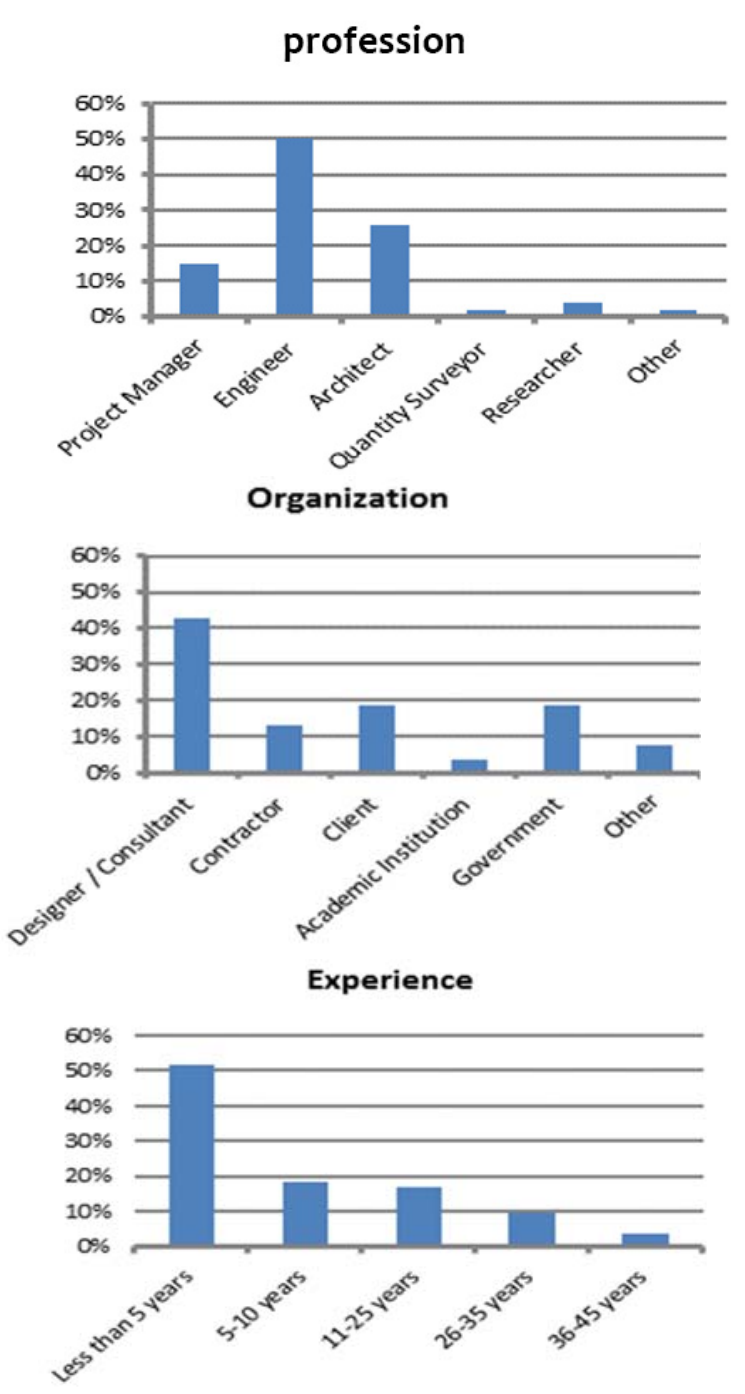

Figure 2. Sub-groups of respondents.

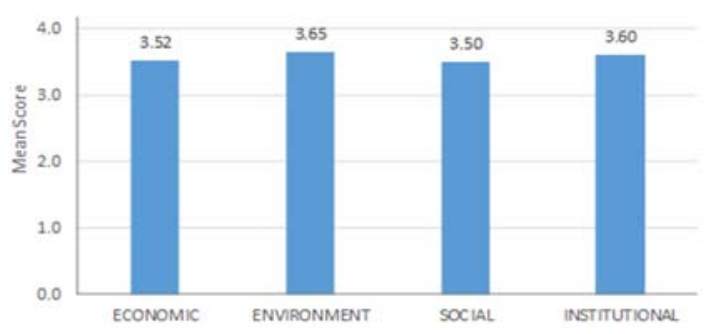

Figure 3. Mean score of each group of factors.

Table 3. Normality of the variables.

\begin{tabular}{|c|c|c|c|c|}
\hline & 异 & 苞 & 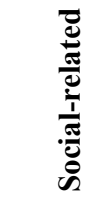 & 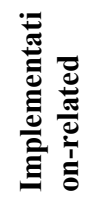 \\
\hline $\begin{array}{l}\text { Kolmogorov- } \\
\text { Smirnov }\end{array}$ & 0.96 & 0.11 & 0.109 & 0.109 \\
\hline Sig. & 0.2 & 0.1 & 0.16 & 0.16 \\
\hline
\end{tabular}


Table 4. Differences between the variables - $\mathrm{t}$ (sig.).

\begin{tabular}{l|llll}
\hline Paired-sample t-test & Economic-related & Environment-related & Social-related & Implementation-related \\
\hline Economic-related & 0 & & & \\
Environment-related & $-1.47(0.148)$ & 0 & 0 & $-2.39(0.02)^{* *}$ \\
Social-related & $0.63(0.53)$ & $3.1(0.00)^{*}$ & 0 \\
Implementation-related & $-1.1(0.28)$ & $0.43(0.67)$ & & \\
$*$ Significant at $0.01, * *$ Significant at 0.05 & & & \\
\hline
\end{tabular}

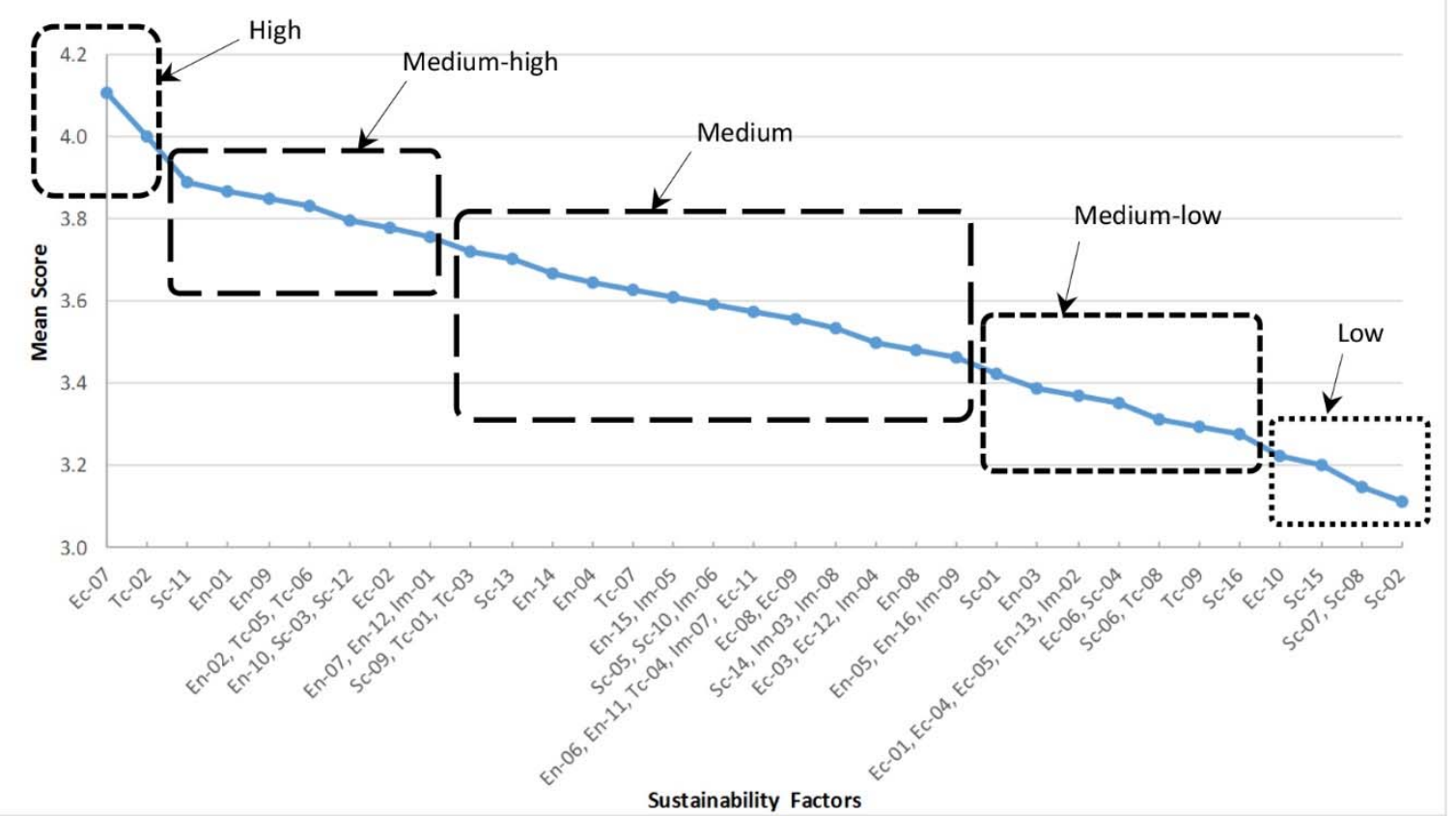

Figure 4. Overall importance of the IBS sustainability factors based on the ranking of these factors.

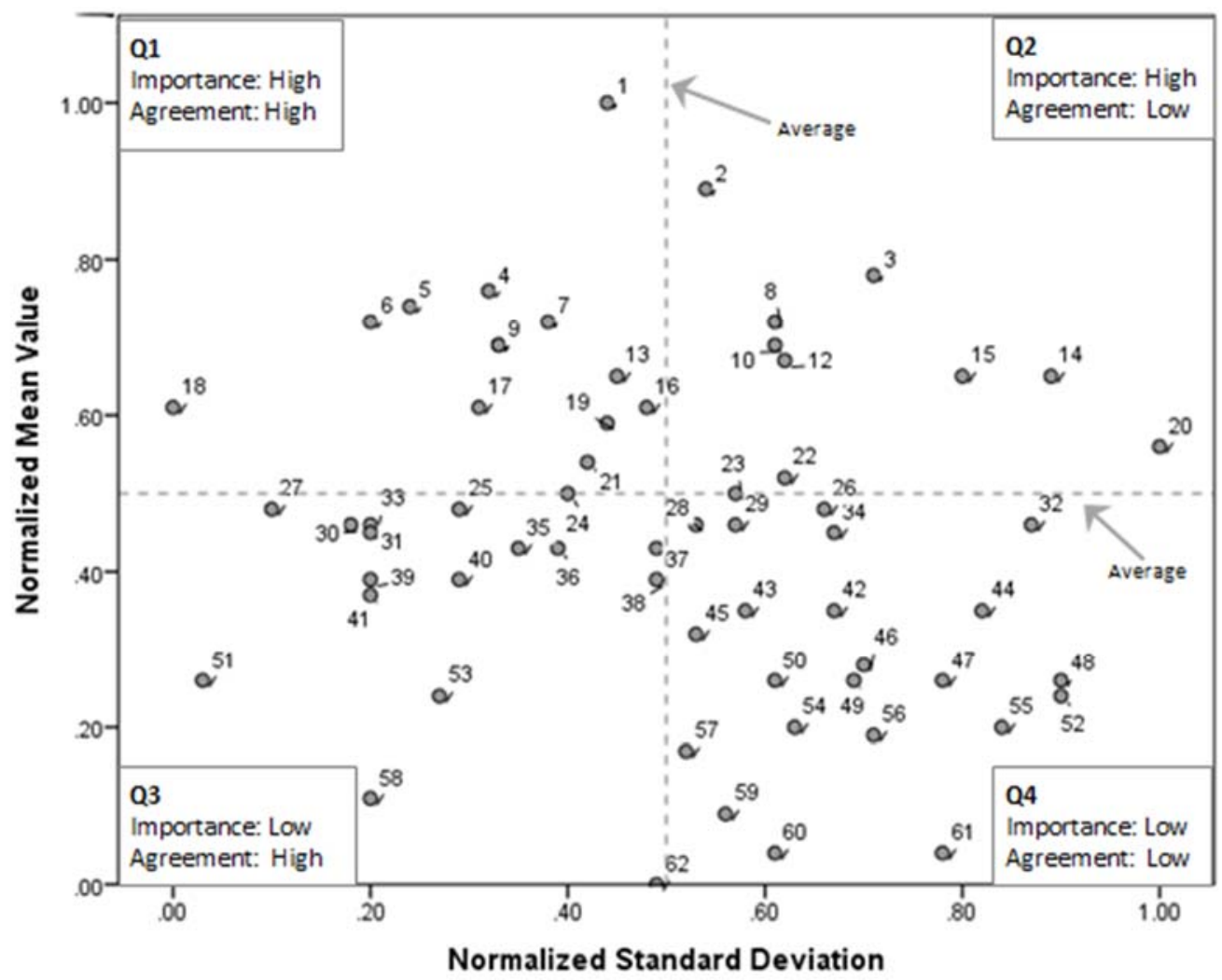

Figure 5. The influence of IBS sustainabililty factors. Each data point represents one factor and the associate number represents the factor's overall rank. 
M. S. Saleh and C. Alalouch

Table 5. Statistical analysis and ranking of sustainability factors for IBS applications in Oman.

\begin{tabular}{|c|c|c|c|c|c|}
\hline \multicolumn{2}{|c|}{$\begin{array}{l}\text { SUSTAINABILITY PERFORMANCE } \\
\text { FACTORS }\end{array}$} & Mean Value* & $\begin{array}{l}\text { Standard } \\
\text { Deviation } \\
\end{array}$ & $\begin{array}{l}\text { Overall } \\
\text { Importance** }\end{array}$ & $\begin{array}{l}\text { Overall } \\
\text { Influence } * * *\end{array}$ \\
\hline \multicolumn{6}{|c|}{ ECONOMIC-RELATED FACTORS } \\
\hline Ec-07 & Construction time & 4.11 & 1.09 & $\mathrm{H}$ & Q1 \\
\hline Ec-02 & Disposal costs & 3.78 & 1.16 & $\mathrm{M}-\mathrm{H}$ & Q2 \\
\hline Ec-11 & Production & 3.57 & 1.25 & M & Q4 \\
\hline Ec-08 & Lead-times & 3.56 & 1.00 & M & Q3 \\
\hline Ec-09 & Speed of return on investment & 3.56 & 1.18 & M & Q4 \\
\hline Ec-03 & Life cycle costs & 3.50 & 1.11 & $\mathrm{M}$ & Q3 \\
\hline Ec-12 & Design stage adoption & 3.50 & 1.00 & M & Q3 \\
\hline Ec-01 & Maintenance and operation costs & 3.37 & 1.22 & M-L & Q4 \\
\hline Ec-04 & Initial construction costs & 3.37 & 1.26 & M-L & Q4 \\
\hline Ec-05 & Material costs & 3.37 & 1.19 & M-L & Q4 \\
\hline Ec-06 & Labour cost & 3.35 & 1.26 & M-L & Q4 \\
\hline Ec-10 & Transportation and lifting & 3. & 1.00 & $\mathrm{~L}$ & Q3 \\
\hline \multicolumn{6}{|c|}{ ENVIRONMENT-RELATED FACTORS } \\
\hline En-01 & Waste generation & 3.87 & 1.05 & $\mathrm{M}-\mathrm{H}$ & Q1 \\
\hline En-09 & Pollution generation & 3.85 & 1.02 & M-H & Q1 \\
\hline En-02 & Waste disposal & 3.83 & 1.00 & $\mathrm{M}-\mathrm{H}$ & Q1 \\
\hline En-10 & Environment administration & 3.80 & 1.05 & $\mathrm{M}-\mathrm{H}$ & Q1 \\
\hline En-07 & Reusable / recyclable elements & 3.76 & 1.10 & $\mathrm{M}-\mathrm{H}$ & Q1 \\
\hline En-12 & Health of occupants (indoor air & 3.76 & 1.26 & $\mathrm{M}-\mathrm{H}$ & Q2 \\
\hline En-14 & Water consumption & 3.67 & 1.30 & M & Q2 \\
\hline En-04 & Energy consumption in design and & 3.65 & 1.08 & M & Q1 \\
\hline En-15 & Land use & 3.61 & 1.14 & M & Q2 \\
\hline En-06 & Recyclable / renewable contents & 3.57 & 1.13 & M & Q4 \\
\hline En-11 & Ecology preservation & 3.57 & 1.14 & M & Q4 \\
\hline En-08 & Site disruption & 3.48 & 1.00 & M & Q3 \\
\hline En-05 & Operational energy & 3.46 & 1.18 & M & Q4 \\
\hline En-16 & Material consumption & 3.46 & 1.14 & M & Q4 \\
\hline En-03 & Embodied energy & 3.39 & 1.19 & M-L & Q4 \\
\hline En-13 & Inclusive environment & 3.37 & 1.15 & M-L & Q4 \\
\hline \multicolumn{6}{|c|}{ SOCIAL-RELATED FACTORS } \\
\hline Sc-11 & Workers' health and safety & 3.89 & 1.19 & $\mathrm{M}-\mathrm{H}$ & $\mathrm{O} 2$ \\
\hline Sc-03 & Community disturbance & 3.80 & 1.16 & $\mathrm{M}-\mathrm{H}$ & Q2 \\
\hline Sc-12 & Working conditions & 3.80 & 1.05 & $\mathrm{M}-\mathrm{H}$ & Q2 \\
\hline Sc-09 & Knowledge and skills & 3.72 & 1.11 & M & Q1 \\
\hline Sc-13 & Disaster preparedness & 3.70 & 1.09 & M & Q1 \\
\hline Sc-05 & Public awareness & 3.59 & 1.04 & M & Q3 \\
\hline Sc-10 & Labor availability & 3.59 & 1.17 & M & Q4 \\
\hline Sc-14 & Site attributes & 3.54 & 1.06 & M & Q3 \\
\hline Sc-01 & Local economy & 3.43 & 1.13 & M-L & Q4 \\
\hline Sc-04 & Traffic congestion & 3.35 & 1.03 & M-L & Q3 \\
\hline Sc-06 & Public participation & 3.31 & 1.16 & M-L & Q4 \\
\hline Sc-16 & Physical space & 3.28 & 1.12 & M-L & Q4 \\
\hline Sc-15 & Aesthetic options & 3.20 & 1.14 & L & Q4 \\
\hline Sc-07 & Principles and values & 3.15 & 1.16 & $\mathrm{~L}$ & Q4 \\
\hline Sc-08 & Influence on job market & 3.15 & 1.22 & $\mathrm{~L}$ & Q4 \\
\hline Sc-02 & Participation and control & 3.11 & 1.11 & $\mathrm{~L}$ & Q3 \\
\hline \multicolumn{6}{|c|}{ IMPLEMENTATION-RELATED FACTORS } \\
\hline Tc-02 & Defects and damages & 4.00 & 1.13 & $\mathrm{H}$ & Q2 \\
\hline Tc-05 & Integration of supply chains & 3.83 & 1.07 & $\mathrm{M}-\mathrm{H}$ & Q1 \\
\hline Tc-06 & Constructability & 3.83 & 1.15 & M-H & Q2 \\
\hline Im-01 & Standardization & 3.76 & 1.23 & $\mathrm{M}-\mathrm{H}$ & Q2 \\
\hline Tc-01 & Durability & 3.72 & 1.05 & M & Q1 \\
\hline Tc-03 & Loading capacity & 3.72 & 0.93 & M & Q1 \\
\hline Tc-07 & Usage efficiency & 3.63 & 1.16 & M & Q2 \\
\hline Im-05 & Building capacity & 3.61 & 1.08 & M & Q3 \\
\hline Im-06 & Design standard and project function & 3.59 & 0.97 & M & Q3 \\
\hline Tc-04 & Integration of building services & 3.57 & 1.00 & M & Q3 \\
\hline Im-07 & Project control guidelines & 3.57 & 1.00 & $\mathrm{M}$ & Q3 \\
\hline Im-03 & Legislation & 3.54 & 1.07 & M & Q3 \\
\hline Im-08 & Integrated environmental and & 3.54 & 1.11 & M & Q3 \\
\hline Im-04 & Policy and strategy match & 3.50 & 1.04 & M & Q3 \\
\hline Im-09 & Procurement system & 3.46 & 1.23 & M & Q4 \\
\hline Im-02 & Governance & 3.37 & 0.94 & M-L & Q3 \\
\hline Tc-08 & Adaptability and flexibility & 3.31 & 1.24 & M-L & Q4 \\
\hline Tc-09 & Technology & 3.30 & 1.19 & M-L & Q4 \\
\hline
\end{tabular}


However, the figure shows that the differences between the groups are marginal. It was necessary therefore to test the statistical significance between the differences in the mean scores of the groups. Therefore, the normality of the data was examined using the One-sample Kolmogorov-Smirnov test (K-S test). The significant value of this test $(\mathrm{p}<0.05)$ indicates a deviation from normality. The results of this test indicated that all variables are normally distributed as shown in Table 3. Hence, the pairedsample t-test was used to check if the differences between the importance of the variables are statically significant.

The results of the test of differences is reported in Table 4, which shows that the Environment-related factors were seen as significantly more important than the social-related factors $(\mathrm{t}=3.1, \mathrm{df}=53, \mathrm{p}<0.01)$. Whereas, the participants valued the Implementationrelated factors significantly more than the socialrelated factors $(\mathrm{t}=-2.39, \mathrm{df}=53, \mathrm{p}<0.05)$. This suggests that the Environment-related and the Implementation-related factors are more important than the social-related factors. In contrast, no significant differences were found between the economic-related factors and any other variable.

\subsubsection{The overall importance of the factors}

The next step was to identify the most important factors among the 62 factors considered in this study. Therefore, the average score for each factor was calculated as shown in Fig. 4. A close examination of the trend line revealed a clear break in the mean score at four points, which suggests that the factors can be split into five levels in terms of importance. The level with the highest important factors contains only two factors namely, Construction Time and Defects and Damages. On the other hand, the low importance level has five factors i.e. Transportation and Lifting, Aesthetic Options, Principles and Values, Influence on Job Market, Participation and Control.

Although Fig. 4 provides an insight into the structure of the importance of each factor based on a simple ranking of the mean score, it does not take into account information regarding the consensus among the participants' answers. In order to explore the relationship between the level of importance and the level of consensus, the mean score and the standard deviation were normalized to render them comparable. Fig. 5 shows a scatter plot between the two normalized variables. In this figure, the average of each axis was used to split the factors into four quarters based on their level of Influence (i.e. importance and consensus). The results show that there is a general consensus about twelve important factors out of the 62 factors included in this study which are shown in the figure in the Q1 quarter (Q1= high mean value with low St. deviation). These factors are: 1-Construction time, 4-Waste generation, 5-Pollution generation, 6-Waste disposal, 7Integration of supply chains, 9-Environment administration, 13-Reusable/recyclable elements, 16Knowledge and skills, 17-Durability, 18-Loading capacity, 19-Disaster preparedness, 21-Energy consumption in design and construction. This suggests that these factors have the highest potential to influence the adoption of IBS in the Omani market.

Table 5 shows the mean score, standard deviation, importance level and influence level for each factor. Construction Time was considered the most important and the most influential factor across all factors. In the Environment-related factors attention should be given to Waste Generation, Pollution Generation, Waste Disposal, Environment administration, and Reusable/recyclable elements. As for the socialrelated factors, Workers' Health and Safety, Community Disturbance and Working Conditions were seen as the most important and most influential factors in this group. The results for the Implementation-related factors are not inclusive.

\section{CONCLUSION}

This study presented the sustainability factors affecting the implementation of IBS in the context of Oman construction industry. The research identified 62 factors based on the main pillars of sustainable development, consisting of 12 economy-related factors, 16 environment-related factors, 16 socialrelated factors, and 18 implementation-related factors. A questionnaire was conducted to investigate the perspective of the Omani construction industry stakeholders on the relative importance of these factors. Analysis of the collected data revealed that environment-related factors were generally considered the most important factors related to IBS, followed by implementation-related factors and social-related factors, while economic-related factors were the least important. The top three environment-related factors included En-01 (Waste generation), En-09 (Pollution generation), and En-02 (Waste disposal). The top three implementation-related factors include Tc-02 (Defects and damages), Tc-05 (Integration of supply chains), and Tc-06 (Constructability). The top three social-related factors include Sc-11 (Workers' health and safety), Sc-03 (Community disturbance), and Sc12 (Working conditions). Finally, the top three economic-related factors include Ec-07 (Construction time), Ec-02 (Disposal costs), and Ec-11 (Production). Equally important, Construction Time was found to be the most important factor and the one that has the highest consistency level concerning its importance.

The Omani government and construction professionals can use the findings of this study as guidelines to focus their effort in promoting the application of IBS in Oman by emphasizing the factors that matter the most to the stakeholders while fitting within the government's short- and long-term strategy and targets. On the other hand, the study provides essential information to the decision-makers in the construction industry to understand the key 
areas where the implementation of IBS practices needs improvement, leading to implement proper actions and management strategies to maximize the benefits of IBS practices. In addition, the findings of this study lay the groundwork for future investigation of effective actions to manage these sustainability factors in the Omani construction industry. Future research in this area should focus on developing measurable "indicators" for each factor that are meaningful for the Omani construction industry and explore the differences in the importance of these factors across building types.

\section{CONFLICT OF INTEREST}

The authors declare no conflicts of interest.

\section{FUNDING}

No funding was received for this project.

\section{ACKNOWLEDGMENT}

The authors would like to acknowledge the Civil and Architectural Engineering Department and Sultan Qaboos University for their support. The authors would like also to thank everyone who was involved in the data collection for this research.

\section{REFERENCES}

Alalouch C, Al-Hajri S, Naser A, Al Hinai A (2019), The impact of space syntax spatial attributes on urban land use in Muscat: Implications for urban sustainability. Sustainable Cities and Society, 46: 101417. https://doi.org/10.1016/j.scs.2019.01.002

Alalouch C, Alsaadi S, AlWaer H, Al-Khaled K (2019), Energy saving potential for residential buildings in hot climates: The case of Oman. Sustainable Cities and Society, 46:101442. https://doi.org/10.1016/j.scs.2019.101442

Alalouch C, Saleh M S, Al-Saadi S (2016), Energyefficient house in the GCC region. Procedia Social and Behavioral Sciences, 216:736-743.

Alkamali N, Alhadhrami N, Alalouch C (2017), Muscat City expansion and Accessibility to the historical core: Space syntax analysis. Energy Procedia, 115:480-486. 10.1016/j.egypro.2017.05.044

Bari N, Abdullah N, Yusuff R, Ismail N, Jaapar A (2012), Environmental Awareness and Benefits of Industrialized Building Systems (IBS). Procedia Social and Behavioral Sciences 50: 392-404.

Birkbeck D, Scoones A (2005), Prefabulous homes: The new housebuilding agenda. Constructing Excellence: London.

CIB. (2010). Industrialised Construction: state of the art report, TG 57 Publication. International Council for Research and Innovation in Buildings and Construction: Zurich.

Cook B (2005), An assessment of the potential contribution of prefabrication to improve the quality of housing: a Scottish perspective. Information Quarterly 7(2): 50-55.

Dawood N (1996), “An integrated intelligent planning approach for modular construction," In Proc. of third Congress on Computers in Civil Engineering. Anaheim, USA.

Ding D (2008), Sustainable construction: the role of environmental assessment tools. Journal of Environmental Management 86(3): 451.

El-Abid K M, Ghazalia F M (2015), Motivations and limitations of prefabricated building: An overview. Applied Mechanics and Materials 802: 668-675.

Finnimore B (1989), Houses from the factory. Unwin Hyman: London.

Gann D M (1996), Construction as a manufacturing process? Similarities and differences between industrialized housing and car production in Japan. Construction Management and Economics 14(5): 437- 450 .

Ghaffarianhoseini A, AlWaer H, Omrany H, Alalouch C, Clements-Croome D, Tookey J (2018), Sick Building Syndrome: Are We Doing Enough? Architectural Science Review 61(3): 99-121. https://doi.org/10.1080/00038628.2018.1461060

Gibb A, Isack F (2003), Re-engineering through preassembly: client expectations and drivers. Building Research and Information 31(2): 146-160.

Goodier C, Gibb A (2007), Future opportunities for offsite in the UK. Construction Management and Economics 25(6): 585-595.

Hampson K, Brandon P (2004), Construction 2020: A vision for Australia's property and construction industry. Cooperative Research Centre for Construction Innovation for Icon: Australia.

Jaillon L, Poon C (2009), Sustainable construction aspects of using prefabrication in dense urban environment. Journal of construction Management and Economics 26(9): 953-966.

Kamaruddin S, Mohammad M, Mahbub R (2013), Enhancing the Quality of Life by Adopting IBS: An Economic Perspective on Mechanisation and Automation. Procedia: Social and Behavioral Sciences 101: 71-80.

Lessing J (2006), Industrialised House-Building Concept and Processes, PhD Thesis, Department of Construction Sciences, Lund Institute of Technology: Sweden.

Lessing J, Stehn L, Ekholm A (2005), “Industrialised housing: definition and categorization of the concept," in Proc. of the in the $13^{\text {th }}$ annual conference in the International Group for Lean Construction, Sydney, Australia.

Luo Y, Riley R, Horman M J, Kremer G O (2008), Decision Support Methodology for Prefabrication Decisions on Green Building Projects. In P. McDermott and M. M. A. Khalfan (Eds.), Symposium on Sustainability and Value through Construction Procurement. University of Salford: UK. 
Nawi M N, Abu Hanifa F A, Kamar K A, Lee A, Azman M N (2014), Modern Method of Construction: An Experience from UK Construction Industry. Australian Journal of Basic and Applied Sciences 8(5): 527-532.

Oxford Business Group (2013), Going Green: sustainable building practices should help address housing shortages. In The Report: Oman 2013.

Oxford Business Group (2018), Omani construction sector weathers external forces to continue posting solid growth. In فhe Report: Oman 2018.

Pasquire C, Gibb A, Blismas N (2004), Off-site Production: Evaluating the drivers and constraints. Paper presented at International Group for Lean Construction: Denmark.

Powmya, A., and Abidin, N. Z. (2014). The challenges of green construction in Oman. International Journal of Sustainable Construction Engineering 5(1): 33-41.

Richard R B (2006), Industrialised, flexible and demountable building systems: quality, economy and sustainability," In Proc. CRIOCM2006: International Research Symposium on Advancement of Construction Management and Real Estate, Beijing.
Saleh M S, Alalouch C (2015), Towards sustainable construction in Oman: challenges and opportunities. Procedia Engineering 118: 177-184.

Song J (2005), Considering Prework on Industrial Projects. Journal of Construction Engineering and Management 131(6): 723-733.

The World Bank (n.d.), Oman Country Data. Retrieved December 15, 2014, from http://data.worldbank.org/country/oman

Timetric (2017), Construction in Oman, Key Trends and Opportunities to 2021. Timetric: USA.

Waskett P (2001), Current Practice and Potential Uses of Prefabrication. Building Research Establishment Ltd (BRE): Watford

Yunus R, Yang J (2011), Sustainability Criteria for Industrialised Building Systems (IBS) in Malaysia. Procedia Engineering 14: 1590-1598.

Zhang X, Skitmore M (2012), Industrialized housing in China: a coin with two sides. International Journal of Strategic Property Management 16(2): 143-157.

Zhang X, Skitmore M, Peng Y (2014), Exploring the challenges to industrialized residential building in China. Habitat International 41: 176-184. 